\title{
Teaching Methods Used by Teachers in Primary Schools Inclusive
}

\author{
*Veronika Veronika \\ Pendidikan Guru Sekolah Dasar, Universitas Kristen SatyaWacana \\ *Corresponding Author Email:292016149@student.uksw.edu
}

\begin{abstract}
This study aims that all children with special needs get the same rights to receive equal education in class together with their age friends. This research is a descriptive study, which seeks to describe the events that exist in the world of education, especially in terms of channeling knowledge to students. The type of research used in this study is qualitative research. The techniques used in collecting data are interview techniques and direct observation in schools. Education and diversity cannot be separated, what needs to be known is how education is able to unite differences by providing good educational equality. Good for normal children and those with special needs. The purpose of education is to encourage good change, both for individuals, groups and even groups. Inclusive education is child-friendly education, which means that from every system that services are provided to students who have learning disabilities or special needs to learn in ordinary class schools along with their friends.
\end{abstract}

Keywords: Inclusive Education, education for all

\begin{abstract}
Abstrak
Penelitian ini bertujuan agar semua anak yang berkebutuhan khusus mendapatkan hak yang sama untuk menerima pendidikan yang setara dikelas bersama dengan teman seusianya. Penelitian ini merupakan penelitian deskriptif, yang berusaha mendeskripsikan kejadian-kejadian yang ada di dunia pendidikan khususnya dalam hal menyalurkan ilmu pengetahuan kepada peserta didik. Jenis penelitian yang digunakan dalam penelitian ini penelitian kualitatif. Teknik yang digunakan dalam pengumpulan datadata adalah dengan teknik wawancara dan observasi langsung di sekolah.Pendidikan dan keanekaragaman tidak bisa dipisahkan, yang perlu untuk diketahui adalah bagaimana pendidikan mampu menyatukan perbedaan dengan memberikan kesetaraan pendidikan yang baik. Baik untuk anakanak normal dan mereka dengan kebutuhan khusus. Tujuan pendidikan untuk mendorong perubahan yang baik, baik untuk individu, kelompok, dan bahkan kelompok. Pendidikan inklusif yaitu pendidikan yang ramah anak, artinya dari setiap sistem yang layanan yang diberikan kepada peserta didik yang memiliki gangguan belajar atau berkebutuhan khusus belajar di sekolah-sekolah dikelas biasa bersama dengan teman-temannya.
\end{abstract}


Kata kunci:Pendidikan Inklusif, pendidikan untuk semua

\section{A. PENDAHULUAN}

Realitas kehidupan masyarakat di Indonesia yaitu multicultural penyebabnya adalah karena kemajemukan yang didapati seperti adanya perbedaan adat istiadat, agama, suku, maupun kebudayaan subkultural, baik itu dari sejarah perjalanan kehidupan dalam bermasyarakat. Kemajemukan ini bisa saja menjadi boomerang yang bisa menjadi kekuatan bangsa Indonesia, tetapi kemajemukan ini juga bisa saja menjadi tidak potensial jika tidak mendapat pembiunaan terus-menerus dan tanpa pengarahan sehingga ini bisa menjadi pemicu terjadinya kehancuran bangsa. Contohnya perebutan wilayah atau mungkin juga pekerjaan, perbedaan keyakinan, perbedaan pandangan, dan kesenjangan sosial hal ini yang bisa menyebabkan terjadinya pergoalakan-pergolakan diberbagai daerah seperti penyerangan kelompok yang dianggap berbeda, tawuran, pembakaran tempat ibadah termasuk didalamnya fasilitas-fasilitas. Hal-hal tersebut terjadi karena belum adanya kesadaran untuk hidup saling menghargai dalam berbedaan yang dialami (toleransi). Sehingga perlu pengawasan dan pembinaan dalam hal ini agar tidak terjadi hal yang demikian tersebut lagi. Karena dapat merusak dan menghambat tatanan sosial yang suharusnya bukan menjadi konflik.

Kemajemukan itu juga terdapat dalam berbagai aspek kehidupan salah satunya adalah aspek pendidikan, terdapat banyak perbedaan baik pada guru, siswa, ataupun warga sekolah yang lainnya perbedaan itu bisa saja dalam hal tampilan fisik, kemampuan berkomunikasi, kemampuan akademik, sikap dan perilaku, sehingga hal ini menjadi sesuatu hal yang biasa untuk dijadikan bahan terjadinya diskriminasi. Anak-anak yang memilikik kekurangan (berkebutuhan khusus) mendapat perlakukan yang tidak adil oleh system pendidikan yang ada di satuan pendidikan. Oleh sebab itu, anakanak yang demikian sudah seharusnya mendapatkan tempat yang mampu mewadahi, mengarahkan, dan membina seperti halnya harus bersekolah di sekolah khusus sekolah luarbiasa (SLB).

Pendidikan inklusif pendidikan khusus bagia nak-anak yang mengalami hambatan dalam belajar, dan ditempatkan pada sekolah berkebutuhan khusus (SLB). Pada umumnya sekolah berkebutuhan khusus tersebut hanya berada di Jakarta, namun sekarang berbagai daerah di Indonesia terutama di sekolahsekolah dasar sudah ada beberapa yang menerapkan. Pendidikan inklusi diresmikan yaitu pada tanggal 11 Agustus 2004 di Kota Bandung Jawa Barat.

Dalam dunia pendidikan sering mendapati peserta didik yang mengalami hambatan dalam belajar, baik hambatan secara fisik maupun non fisik. Sehingga dari ini peserta didik perlu mendapatkan perhatian serta pendampingan dari pendidik. Melalui penulisan artikel ini bertujuan agar pendidik mampu membantu peserta didik yang mengalami hambatan tersebut dan dengan harapan agar mampu menyesuaikan dengan yang lainnya. Manfaat artikel ini agar pendidik mampu mewujudkan pendidikan untuk semua, tanpa memandang latar belakang, kelainan, ras, suku, agama, bahkan karakteristik peserta didik.

\section{B. PEMBAHASAN \\ 1. Pendidikan Inklusif}

Inklusif secara terminology berasal dari bahasa Inggris yaitu inclusion yang artinya termasuknya atau pemasukan. Inklusif ini digunakan untuk mewadahi dan mendidik siswa yang memiliki hambatan dalam belajar. Pendidikan inklusif merujuk kepada pendidikan yang diselenggarakan untuk semua siswa yang berusahan menjangkau semua siswa tanpa terkecuali. Terjadinya perubahan dalam pendidkan inklusif memiliki arti yang sangat penting terlebih bagi anak yang berkebutuhan 
khusus atau bakat istimewa. Dalam pendidikan inklusif ini siswa berkesempatan untuk berpartisipasi dalam setiap kegiatan di dalam pembelajaran kelas yang berlangsung, tanpa membedabeda seperti membedakan kelainan, ras, suku, agama, bahkan karakteristik yang ada pada peserta didik.

\section{Hubungan Pendidikan InklusidenganFalsafah Indonesia}

Di Indonesia pendidikaninklusifdalampenerapannyadila ndasi oleh Pancasila yang didalamnyamemuat lima pilar yang menjadicita-cita/pondasi, yang lebihmendasarlagidisebutsebagaiBhineka

Tunggal Ika yang artinyaberbedabedatetapitetapsatu,

darisinisudahsangatjelasbahwa di

Indonesia mengakuiadanyaperbedaan yang harusdipersatukandengansikapsalingmeng hargai (toleransi) antarasatudengan yang lainnya. Tidaklepas juga darihakasasi yang dimiliki oleh anak-anakyaitu:

Semuaanakmemilikihakuntukbelajar,

Anak-anaktidakuntukdidiskriminasi,

Anak-anaktidakuntukdikucilkan.

BertolakdariartiBhineka

Tunggal

Ikayaituberbeda-bedatetapitetapsatu,

keterbatasanataupunhambatanbelajar yang alami oleh siswaadalah salah satualasandiberdirikannyapendidikan yang berkualitasbagisemuasiswatanpamembeda

-bedakan melalui penyusunan kurikulum yang tepat, pengorganisasian yang baik, pemilihan strategi belajar dan pengajaran yang tepat, pemanfaatan sumber-sumber belajar yang mendukung, dan penggalangan-penggalangan dengan masyarakat sekitar.

Bentuk daripada kebhinekaan itu sama hal dengan adanya perbedaan suku, bahasa budaya, ras, atau agama. Sama halnya dengan keadaan dimana ditemukan kelainan dalam diri individu pasti juga akan ditemukan keunggulan-keunggulan tertentu, demikian sebaliknya pada individu yang berbakat pasti terdapat juga kecacatan tertentu, karena tidak hanya makhluk di bumi ini yang diciptakan sempurna. Perbedaan seperti kecacatan dan keunggulan akan tetap mampu menyatukan antara peserta didik yang satu dengan lainnya, sama sepertibentuk daripada kebhinekaan. Dalam pendidikan hal inilah yang sangat perlu diwujudkan dalam sistem pendidikan di Indonesia. Dalam sistem pendidikan harus tetap ada interaksi dan komunikasi antara siswa yang berada dalam keberagaman, ini mendorong tumbuhnya sikap saling menerima, saling membimbing, saling menginggatkan, bahkan menajamkan pikiran pada saat proses pembelajaran berlangsung, intinya tumbuh sikap saling toleransi seperti halnya yang dicitacitakan oleh falsafah negara Indonesia, dalam wujudnyatanya di kehidupan sehari-hari.

Undang-undang Dasar yang mengatur tentang pendidikan bagi anak berkebutuhan khusus (ABK) yaitu pada Undang-Undang Dasar Republik Indonesia 1945 terdapat pasal-pasal mengenai hak asasi manusia yang salah satunya hak untuk mendapatkan pendidikan yaitu pada pasal 28C ayat (1), Undang-undang Republik Indonesia NO. 4 Tahun 2003 tentang Sistem Pendidikan Nasional, PERMENDIKNAS nomor 70 tahun 2009 tentang pendidkan inklusif bagi bagi anak berkebutuhan khusus, anak cerdas istimewa dan bakat istimewa. Sedangkan untuk pelaksanaannya diatur dalam PERDA masing-masing daerah di Indonesia.

\section{Sekolah dan Model Pembelajaran Pendidikan Inklusif}

Sekolah yang menyelenggarakan pendidikan inklusif dengan 
mengakomodasikan seluruh peserta didik tanpa terkecuali, baik normal maupun anak yang berkebutuhan khusus yaitu anak-anak yang memiliki kelainan fisik, mental, intelektual, sosial, emosi, cerda, berbakat istimewa, miskin, berbeda gender, ras, suku, agama, budaya, kelompok sosial dalam masyarakat dan lain sebagainya, inilah yang disebut Sekolah Inklusif. Sekolah ini mampu mengenali bahkan memahami kebutuhankebutuhan dari setiap siswanya yang berbeda-beda, menyediakan beragam gaya dan kecep;atan belajar, bahkan menjamin mampu memberikan pendidkan yang jauh lebih baik, dengan penyusunan kurikulum yang tepat, pemanfaatan sumber-sumber yang ada, dan juga membangun kemitraan dengan masyarakat sekitarnya.

Model pembelajaran guru di
sekolah pengidentifikasian secara tepat pada setiap sasaran dari setiap proses pembelajaran yang memungkinkan bagi seorang guru. Pengidentifikasian ini disesuaikan dengan peserta didik yaitu antara kesesuaiannya dengan kesiapan dirinya untuk mampu menerima materi atau tugas-tugas pembelajaran, dan sasaran anatar yang ingin dituju. Inti model pembelajaran berdsarkan pada Kurikulum Berbasis Kompetensi atau KBK bagi Anak Berkebutuhn Khusus adalah pengembangan lingkungan belajar secara terpadu.

Prinsip-prinsip umum pembelajaran meliputi motivasi, konteks, keterangan, hubungan sosial, belajar sambil bekerja, individualisasi, menemukan dan prinsip. Sedangkan prinsip khusus disesuaikan dengan karakteristik khusus dari setiap penyandang kelainan. Misal, seorang peserta didik yang memiliki hambatan visual, maka perlu prinsip konkrit, pengalama, dan belajar sambil melakukannya. Untuk siswa yang yang mengalami kesulitan mendengar dan berbicara diperlukan prinsip keterarahanwajah. Peserta didik dengan hambatan mengatasi emosinya maka diperlukan prinsip kebutuhan dan kearifan, kebebasan yang mengarah, kekeluargaan, kepatuhan kepada orang tua, pemanfaatan waktu luang, setia kawan, perlindungan, disiplin, minat, dan kasih sayang. Peserta didik yang mengalami kesulitan dalam berpikir maka prinsip yang diperlukan antara lain pengulangan, memberikan contoh dan juga arahan, pemecahan materi, kasih sayang ketekunan, dan lain sebagainya (Observasi, 2 Februari 2019).

\section{Guru di Sekolah Inklusi yang Tangguh}

Tugas utama guru pada dasarnya mendidik, membimbing, dan mengajar, guru sebagai jalan atau wadah untuk memampukan siswa menerima ilmu pengetahuan, guru medium aktif untuk mengembangkan pribadi siswa juga mendekatkannya degan pengaruh yang baik dari luar dan menjauhkan pengaruh yang buruknya juga (Hidayat, 2009). Oleh karena tugas guru yang demikian sehingga guru diwajibkan memiliki pengetahuan, sisfat-sifat kepribadian, serta kesehatan jasmani dan rohani. Untuk menjadi guru di sekolah inklusi yang tangguh ada 3 kemampuan yang harus ada pada guru tersebut yaitu:

Pertama, Kemampuan Umum disini guru memiliki ciri warga Negara Indonesia yang religious dan berkpribadian, sikap dan kemampuan yang mampu mengaktualisasikan dirinya sebagai warga Negara Indonesia, sikap dan kemampuan mengakui bahkan menghargai keberagaman yang ada pada peserta didiknya, sehingga pada saat proses 
pembelajaran tidak terjadi

ketidakadilan.

Kedua, Kemampuan Dasar

disini guru mampu mengidentifikasi anak yang berkebutuha khusus, guru juga harus mampu memahami konsep dan merancang, melaksanakan serta mengevaluasikan pembelajaran bagi peserta didiknya, guru mampu melayani dan membimbing peserta didik dengan baik, guru mampu menyusun kurikulum yang baik dan sesuai dengan kebutuhan dn kemampuan yang dimiliki peserta didiknya.

Ketiga, Kemampuan Khusus, disini guru mampu melakukan modifikasi terhadap perilaku siswanya, menguasai konsep juga keterampilan belajar yang sesuai dengan kemampuan anak yang mengalami gangguan/kelainan penglihatan, guru menguasai konsep dan keterampilan pembelajaran bagi peserta didik yang mengalami gangguan/kelainan anggota tubuh dan gerakan, guru mampu menguasai konsep dan keterampilan pembelajaran bagi peserta didik yang mengalami gangguan/kelainan pendengaran/komunikasi, guru konsep dak keterampilan pembelajaran bagi peserta didik yang mengalami gangguan/kelainan intelektual dan lamban dalam belajar, guru menguasai konsep bagi peserta didik yang mengalami hambatan perilaku dan sosial dan guru juga harus mampu menguasai konsep dan keterampilan pembelajaran bagi peserta didik yang mengalami hambatan dan kesulitan dalam belajar.

Menurut Eka Surahman, 2014:130-141) guru seharusnya mampu menciptakan suasana yang mampu mendorong peserta didik untuk berfikir, bertindak, berkreasi, sehingga dapat mengekspresikan ide-ide dan kreativitasnya secara bebas namun dalam batas norma-norma yang ditegakkan secara konsisten.

\section{Kerjasama Guru dan Orang Tua Peserta Didik ABK}

Bagi orang tua peserta didik dengan kebutuhan khusu atau tambahan, jalan menuju pra-sekolah terasa sangat sukar dan terjal, diwarnai mungkin juga dengan peserta harus dirawat inap, adanya janji-janji untuk melakukan pertemuan dengan para ahli, dan hal ini diulangi terus-menerus. Banyak orang tua yang sudah berusaha memahami kondisi anaknya dan memikirkan cara-cara yang terbaik untuk memenuhi kebutuhan anaknya. Pengajar harus bisa memanfaatkan pengetahuan yang dimiliki orang tua dan memahami bahwa meninggalkan anak yang rentan di prasekolah merupakan langkah yang berat bagi para orang tua. Orang tua harus bisa mempercayai pengajar dan merasa yalin bawa mereka, sebagai orang tua, akan diijinkan terlibat dalam kemajuan anak selama prasekolah. Para pengajar pendidikan dini memahami pentingnya kerjasama dengan seluruh orang tua dan sering bekerja keras untuk meyakinkan bahwa orang tua akan terlibat dalam setiap aspek pendidkan dan perawatan anak. Jeynes (2011:112) menyatakan dengan melibatkan orang tua dalam penyelenggraan pendidikan anak-anak mereka adalah salah satu ide atau inisiatif mendorong partisipasi orang tua peserta didik.

Orang tua sebagai mitra karena anak mendapat pendidikan pertama itu dari orangtuanya. Maka pengajar juga perlu mengajak orang tua [eserta didik untuk bekerja sama dalam pendidikan, hasilnya akan berdampak positif pada 
pembelajaran dan perkembangan anak. Strategi sepuluh tahun pemerintahan Inggris menyangkut kepedulian anak, pilihan untuk orang tua, awal terbaik untuk anak, menjanjikan terbentuknya sebuah kerangka kerja pembelajaran dan perkembangan manunggal untuk anak. Sejak Sepetember 2008 EFYS (Early ears Foundation Stage), merupakan kerangka kerja yang relevan dan berperan penting dalam membantu anak menapai 5 kompetensi. Dalam EFYS ini menekankan pentingnya kerja sama denganorang tua yang mempunyai anak dengan kebutuhan khusus atau tambahan. EFYS memiliki 4 prinsip yaitu diantaranya saling melengkapi keunikan anak, hubungan positif, lingkungan yang memadai, dan pembelajaran dan perkembangan.

Pedoman undang-undang juga menjabarkanbahwa EFYS dirancang untuk menciptakan kesetaraan kesempatan dan kerangka kerja sama sebagai penentu keberhasilan penyampaian EFYS, (1) Menjalin kerja sama dengan orang tua, tujuannya untuk mengetahui kebutuhan pembelajarana anak danmemastikan adanya respon cepat pada setiap kesulitan, karena orang tua dan keluarga itu tempat paling nyaman untuk anak, dan pengajar harus mendukung hubungan penting ini dengan cara saling berbagi informasi dan menawarkan dukungan pembelajaran di rumah. (2) Menjalin kerja sama dengan pihak lain, pihak lain disini misalnya dinas kesehatan masyarakat lokal, atau tempat anak tersebut di lindungi oleh pemerintah lokal, tujuan kerja sama ini untuk mengetahui bahkan memenuhi kebutuhan menggunakan pengetahuan dan saran mereka guna memberikan perlindungan sosial kepada anak melalui kesempatan dan lingkungan belajar terbaik untuk anak. (3) Memberikan kesetaraan kesempatan, tujuannya anak mampu menghargai keberagaman yang dimiliki orang lain dan tumbuh dengan memberikan sumbangan positif untuk masyarakat. Maka dari itu penyedia layanan pendidikan bertanggungjawab menjamin sikap positif terhadap perbedaan dan keragaman. Orang tua sebagai mitra karena anak mendapat pendidikan pertama itu dari orangtuanya. Maka pengajar juga perlu mengajak orang tua peserta didik untuk bekerja sama dalam pendidikan, hasilnya akan berdampak positif pada pembelajaran dan perkembangan anak (Chris \& Maggie, 2009:5-6).

\section{METODE}

Dalam penelitian ini metode yang digunakan yaitu metode deskriptif. Seperti dikemukakan oleh Nawawi (2015:67) mengartikan metode ini sebagi sebuah prosedur pemecahan dan penyelidikkan masalah yang ada dengan menggambarkan keadaan objek atau subjek dalam penelitian yang didasarkan pada fakta-fakta yang terlihat. Pendekatan yang digunakan dalam penelitian penulis adalah kualitatif, dimana suatu pendekatan penelitian yang mengungkap situasi sosial tertentu dengan cara mendeskripsikan keadaan objek yang sebenarnya, Aan Komariah (2014:25). Teknik pengumpulan data dalam penelitian ini dengan wawancara dan observasi langsung ke sekolah. Menurut Maryadi (2010:14), Teknik dalam mengumpulkan data secara kualitatif adalah teknik yang mampu membantu memperoleh data detail dengan waktu yang relatif lama. Lebih lanjut pengertian wawancara menurut 
Sugiyono (2010:194), wawancara digunakan sebagai teknik dalam pengumpulan data jika peneliti akan melaksanakan penelitian dalam melaksanakan pendahuluan untuk menemukan permasalahan yang harus diteliti, dan hal-hal yang ingin diketahui dari respondennya secara lebih mendalam.

\section{PENUTUP}

Di Indonesia ideologi dan citacita dalam dunia pendidikannya yaitu pendidikan inklusi dalam hal ini dirancang untuk mewujudkan pendidikan yang adil bagi seluruh peserta didik. Pendidikan inklusi disini sebagi penerima sekaligus pelayanan kepada peserta didik yang memiliki hambatan di dalam belajar. Di sekolah inklusi sangat diperlukan guru yang tangguh dan mampu menciptakan iklim kelas yang ramah. Dengan harapan, seluruh peserta didik akan merasa diakui, dihargai, dan diberlakukan adil dalam keberadaannya di dalam kelas. sehingga, baik peserta didik yang normal maupun yang berkebutuhan khusus dibiasakan guru untuk belajar dan hidup berdampingan, agar ketika kelak pesrta didik tersebut dewasa tidak menimbulkan pikiran-pikiran negatif yang bisa menimbulkan kesenjangan sosial. Sekolah yang ramah (Welcoming School), yaitu sekolah yang di dalamnya guru dan peserta didik bekerjasama untuk meminimalkan hambatan-hambatan yang dialami peserta didik dalam belajar dan juga mempromsikan keikutsertaaan dari seluruh peserta didik. Dalam pernyataan Salamanca (Salamanca Statement 1994) sekolah yang ramah (Welcoming School), sudah ditetapkan dalam konferensi dunia tentang Pendidikan Kebutuhan Khusus tahun
1994 yang mengakui bahwa "Pendidikan untuk Semua" (Educatin for All) sebagai suatu institusi. Maka dapat dimaknai bahwa setiap anak dapat belajar (all children can learn), setiap anak berbeda (eah children are different) dan perbedaan itu merupakan sebuah kekuatan (different ist a strength), dengan demikian kualitas proses dalam belajar perlu ditingkatkan melalui kerjasama antara peserta didik, guru, orang tua, bahkan juga masyarakat.

Inklusif secara terminologi dari bahasa Inggris yaitu inclusion yang artinya : termasuknya atau pemasukan. Inklusif ini digunakan untuk mewadahi dan mendidik peserta didik yang memiliki hambatan dalam belajar. Di dalam pendidikan inklusif ini siswa berkesempatan berpartisipasi dalam setiap kegiatan kelas yang berlangsung, tanpa membeda-bedakan seperti membedakan kelainan, ras, maupun karakteristik peserta didik. Undangundang Dasar Republik Indonesia 1945 terdapat pasal-pasal mengenai hak asasi manusia yang salah satunya hak untuk mendapatkan pendidikan yaitu pada pasal 28C ayat (1), Undang-undang Republik Indonesia NO. 4 Tahun 2003 tentang Sistem Pendidikan Nasional, PERMENDIKNAS nomor 70 tahun 2009, (Juang \& Hidayat:48) tentang pendidkan inklusif bagi bagi anak berkebutuhan khusus, anak cerdas istimewa dan bakat istimewa. Sedangkan untuk pelaksanaannya diatur dalam PERDA masing-masing daerah di Indonesia.

Model pembelajaran guru di sekolah inklusif melakukan pengidentifikasian secara tepat pada setiap sasaran dari setiap proses pembelajaran yang memungkinkan bagi 
seorang guru. Pengidentifikasian ini disesuaikan dengan peserta didik yaitu antara kesesuaiannya dengan kesiapan dirinya untuk mampu menerima materi atau tugas-tugas pembelajaran, dan sasaran anatar yang ingin dituju. Inti model pembelajaran berdsarkan pada Kurikulum Berbasis Kompetensi atau KBK bagi Anak Berkebutuhan Khusus adalah pengembangan lingkungan belajar secara terpadu. Untuk menjadi guru di sekolah inklusi yang tangguh ada 3 kemampuan yang harus ada pada guru tersebut yaitu: Pertama, Kemampuan Umum disini guru memiliki ciri warga Negara Indonesia yang religious dan berkpribadian, sikap dan kemampuan yang mampu mengaktualisasikan dirinya sebagai warga Negara Indonesia, sikap dan kemampuan mengakui bahkan menghargai keberagaman yang ada pada peserta didiknya, sehingga pada saat proses pembelajaran tidak terjadi ketidakadilan.

Kedua, Kemampuan Dasar disini guru mampu mengidentifikasi anak yang berkebutuha khusus, guru juga harus mampu memahami konsep dan merancang, melaksanakan serta mengevaluasikan pembelajaran bagi peserta didiknya, guru mampu melayani dan membimbing peserta didik dengan baik, guru mampu menyusun kurikulum yang baik dan sesuai dengan kebutuhan dn kemampuan yang dimiliki peserta didiknya.

Ketiga, Kemampuan Khusus, disini guru mampu melakukan modifikasi terhadap perilaku siswanya, menguasai konsep juga keterampilan belajar yang sesuai dengan kemampuan anak yang mengalami gangguan/kelainan penglihatan, guru menguasai konsep dan keterampilan pembelajaran bagi peserta didik yang mengalami gangguan/kelainan anggota tubuh dan gerakan, guru mampu menguasai konsep dan keterampilan pembelajaran bagi peserta didik yang mengalami gangguan/kelainan pendengaran/komunikasi, guru konsep dak keterampilan pembelajaran bagi peserta didik yang mengalami gangguan/kelainan intelektual dan lamban dalam belajar, guru menguasai konsep bagi peserta didik yang mengalami hambatan perilaku dan sosial dan guru juga harus mampu menguasai konsep dan keterampilan pembelajaran bagi peserta didik yang mengalami hambatan dan kesulitan dalam belajar.

\section{DAFTAR PUSTAKA}

Baharuddin, E. Reading Approach Use, Effectiveness And EFL Reading Comprehension In University Muhammadiyah Of Parepare.

Berikutnya, D. M. P. Kepemimpinan Moral Spritual Kepala PAUD dalam Meningkatkan Pembelajaran Karakter Anak Usia Dini.

Cultura, L. (2017). INCREASING STUDENTS'READING COMPREHENSION THROUGH COGNITIVE STRATEGIES OF SENIOR HIGH SCHOOL OF SIDENRENG RAPPANG REGENCY. Lingua, 11(2), 103-107.

Chris \& Maggie (2009). Cara Menangani Anak Berkebutuhan Pendidikan 
Khusus: Panduan Guru dan Orang Tua. Jakarta: PT Indeks

Eka suryarahman, Hastuti. (2014). Kinerja Guru IPS SMP Bersertifikasi profesi.

Elihami, E. (2016). Meningkatkan Hasil Belajar Al-Islam Dan Kemuhammadiyahan Melalui Kuis Dengan Umpan Balik Pada Mahasiswa Kelas. SAFINA: Jurnal Pendidikan Agama Islam, 1(2), 27-37.

Elihami, E., \& Syarif, I. (2017, November). Leadership Management And Education Planning: Developing The Entrepreneurship Training Of Islamic Education. In International Conference On Education (Vol. 1, No. 01).

Elihami, E., Suparman, S., Busa, Y., \& Saharuddin, A. (2019). PEMBELAJARAN

KOOPERATIF MODEL THINK-PAIR-SHARE

DALAM DUNIA

IPTEK. Prosiding, 4(1).

Elihami, E., \& Saharuddin, A. (2017). PERAN TEKNOLOGI PEMBELAJARAN ISLAM DALAM ORGANISASI BELAJAR. Edumaspul-Jurnal Pendidikan, 1(1), 1-8.

Elihami, E., \& Nurhayani, N. PENINGKATAN

KEMAMPUAN

BERBICARA ANAK

MELALUI MEDIA PAPAN

FLANNEL DI KELOMPOK BERMAIN.
Elihami, E., \& Firawati, F. (2017). Transformasi Sosial dalam Nilai-Nilai Pendidikan Islam di Kabupaten Sidenreng Rappang. Edumaspul-Jurnal Pendidikan, 1(2), 51-60.

Elihami, E., \& Syahid, A. (2018). PENERAPAN PEMBELAJARAN PENDIDIKAN AGAMA ISLAM DALAM MEMBENTUK KARAKTER PRIBADI YANG ISLAMI. Edumaspul-Jurnal Pendidikan, 2(1), 79-96.

Firawati, F. (2017). Transformasi Sosial dalam Nilai-Nilai Pendidikan Islam di Kabupaten Sidenreng Rappang. Edumaspul-Jurnal Pendidikan, 1(1), 25-35.

Harmoni Sosial Junal pendidkan IPS. Volume 1, No. 2, 2014, pp. 130-141

Jeynes, William, H. (2011).Parental Involvement and Academic Succes. New York: Routledge

Juang \& Hidayat. (2016). Desain Pembelajaran Anak Berkebutuhan Khusus dalam Kelas Inklusif

Nawawi, Hadari. (2015). Metode Penelitian Bidang Sosial. Yogyakarta: Gadjah Mada Erlangga

Hidayat (2009). Pengenalan dan identifikasi anak berkebutuhan khusus dan strategi pembelajarannya. Balikpapan: Kegiatan Workshop 
Jurnal Edumaspul, 3 (1), Year 2019 - 47

Sugiyono. (2015). Metodologi Penelitian

Pendekatan
Pendidikan

Kuantitatif,
Kualitatif dan $R \& D$. Bandung: Alfabeta 